\title{
PENERAPAN PENDEKATAN SAINTIFIK PADA MATA PELAJARAN BIOLOGI DI KELAS XI IIS 3 SMAN JAYALOKA TAHUN PELAJARAN 2014/2015
}

\author{
Idha Rakhmawati \\ SMA NEGERI JAYALOKA \\ DINAS PENDIDIKAN KABUPATEN MUSI RAWAS \\ ibu_io@yahoo.co.id
}

\begin{abstract}
ABSTRAK
Pembelajaran Biologi di kelas Ilmu Pengetahuan Sosial (IPS) pada XI IIS 3 sebagai mata pelajaran peminatan belum sepenuhnya menerapkan pendekatan saintfik, sehingga siswa kurang aktif, motivasi dan minat siswa terhadap pembelajaran, dan menyebabkan rendahnya kemampuan mengamati, menanya, mencoba, mengumpulkan informasi dan mengkomunikasikan. Tujuan penelitian ini adalah untuk mengetahui motivasi dan minat terhadap pembelajaran setelah diterapkan pembelajaran dengan pendekatan saintifik. Penelitian ini merupakan penelitian tindakan kelas (PTK). Sasaran dalam penelitian ini adalah siswa kelas XI IIS 3 SMAN Jayaloka tahun pelajaran 2014/2015 yang berjumlah 26 siswa. Metode pengumpulan data yang digunakan adalah observasi, angket dan tes. Data yang diperoleh selanjutnya dianalisis secara deskriptif kualitatif. 'Dari data siklus terakhir didapatkan hasil bahwa secara umum proses pembelajaran dengan pendekatan saintifik sudah terlaksana dengan baik. Respon motivasi siswa terhadap pembelajarn tergolong baik yaitu aspek attention (perhatian), relevance (relevansi), convidence (percaya diri), dan satisfaction (kepuasan) berturut turut yaitu 3,$72 ; 3.72 ; 3.60$ dan 3.92. Respon minat siswa terhadap pembelajaran tergolong baik yaitu aspek attention (perhatian), relevance (relevansi), convidence (percaya diri), dan satisfaction (kepuasan) berturut-turut adalah 3,86; 3,77; 3,93 dan 4,01. Perolehan tes hasil belajar menunjukkan bahwa ketuntasan siswa mencapai ketuntasan96,15\%. Berdasarkan hasil penelitian tersebut dapat disimpulkan bahwa pembelajaran biologi yang menerapkan pendekatan saintifik pada kelas XI IIS 3 dapat dilaksanakan dengan baik dan mampu meningkatkan minat, memotivasi dan hasil belajar.
\end{abstract}

Kata kunci: Pendekatan saintifik, minat, motivasi, hasil belajar

\section{PENDAHULUAN}

Kurikulum 2013 menganut pandangan dasar bahwa pengetahuan tidak dapat dipindahkan begitu saja dari guru ke peserta didik. Peserta didik adalah subjek yang memiliki kemampuan untuk secara aktif mencari, mengolah, mengkonstruksi, dan menggunakan pengetahuan. Untuk itu pembelajaran harus berkenaan dengan kesempatan yang diberikan kepada peserta didik untuk mengkonstruksi pengetahuan dalam proses kognitifnya. Agar benar-benar memahami dan dapat menerapkan pengetahuan, peserta didik perlu didorong untuk bekerja memecahkan masalah, menemukan segala sesuatu untuk dirinya, dan berupaya keras mewujudkan ide-idenya. 
Dari hasil observasi siswa XI IIS 3 belum aktif dalam proses pembelajaran. Oleh karena itu peneliti mencoba menggunakan pendekatan saintifik untuk memotivasi siswa dalam belajar.

Menurut Kamus Besar Bahasa Indonesia (2008:740) Pendekatan adalah cara teratur diakhiri dengan proses evaluasi hasil belajar, disisi siswa hasil belajar merupakan puncak proses belajar." Menurut Sudjana dalam Adang Heriawan dkk (2012:73) Pendekatan mengajar adalah cara yang dipergunakan guru dalam mengadakan hubungan dengan siswa pada saat berlangsungnya pengajaran, peranan Pendekatan mengajar sebagai alat untuk menciptakan proses mengajar dan belajar. Dari beberapa pendapat di atas dapat disimpulkan bahwa pendekatan adalah cara yang digunakan oleh seseorang dalam melaksanakan suatu pekerjaan. Dalam hal ini adalah caracara dilakukan oleh guru dan peserta didik dalam melaksanakan kegiatan pembelajaran sesuai dengan tujuan yang diharapkan.

Pembelajaran dengan pendekatan saintifik adalah pembelajaran yang terdiri atas kegiatan mengamati (untuk mengidentifikasi hal - hal yang ingin diketahui, merumuskan pertanyaan,mencoba/mengumpulkan data (informasi) dengan bebagai teknik, mengasosiasi/manganalisis,/mengolah

data dan menarik kesimpulan serta mengkomunikasikan hasil yang terdiri dari kesimpulan untuk mempperoleh pengetahuan, keterampilan dan sikap (www.dadangjsn.blogspot.com/2014/06)

Berdasarkan Permendikbud No.81A tahun 2013 tentang Implementasi Kurikulum 2013, langkah-langkah pembelajaran dengan pendekatan saintifik adalah sebagai berikut ;
(a)Mengamati;
(c)Mengumpulkan
(b)Menanya;

Informasi;(d)Mengasosiasi;(e)Mengkom unikasikan.

Motivasi merupakan suatu proses internal yang mengaktifkan, membimbing, dan mempertahankan perilaku dalam rentang waktu tertentu (Nur, 1998). Peserrta didik akan belajar sungguh-sungguh apabila memiliki motivasi yang tinggi. Dengan kata lain, seorang peserta didik akan belajar apabila ada factor pendorongnya (motivasi). Menurut Soeparman (2003) agar dapat memotivasi siswa untuk belajar ada 4 syarat yang harus dipenuhi, yaitu:

\section{Perhatian (Attention)}

Syarat pertama adalah memperoleh dan mempertahankan perhatian siswa. Dalam proses belajar mengajar, perhatian siswa harus diarahkan pada pokok pembicaraan, misalnya dengan melkaukan suatu demonstrasi yang menarik yang berhubungan pada topic bahasan atau dengan suatu cerita atau pertanyaan yang berhubungan dengan topik yang kita ajarkan dan mengarahkan pada sesuatu yang menarik pada saat itu atau dengan memanfaatkan humor secara efektif disela-sela pembelajaran untuk menarik perhatian siswa. Pemberian perhatian yang cukup dari guru kepada peserta didik akan membawa dampak psikologi yang baik bagi anak.

Menurut Nur (1998) menjelaskan bahwa elemen pembelajaran berdasarkan pengamatan terdiri atas perhatian, pengulangan, produksi dan motivasi serta penguatan. Dimana agar siswa dapat melakukan pengulangan maupun produksi dari suatu perilaku, siswa harus memiliki perhatian terhadap perilaku tersebut. Sehingga di sini guru harus dapat menjamin agar siswa memberikan perhatian kepada bagianbagian penting dari materi pelajaran tersebut.

2. Keterkaitan (Relevance) 
Seorang guru harus dapat meyakinkan siswa, bahwa pelajaran yang diikutinya berkaitan dengan tujuan atau motif pribadi mereka, misalnya membantu siswa untuk sampai pada tujuan, baik tujuan jangka panjang maupun jangka pendek dengan mencoba menghubungkan manfaat pelajaran yang dipelajarinya dengan penerimaan ke jenjng studi yang lebih itnggi ataupun untuk mendapat nilai yang bagus. Kesesuaian dalam pemberian materi pelajaran akan mebuat peserta didik lebih berminat dan bersemangat dalam mengikuti proses belajar.

Keterkaitan juga merupakan aspek yang sangat openting untuk terfus dikembangkan, sebab relevansi merupakan dasar bagi siswa untuk dapat menemukan dan membangun pengetahuan dalam diir siswa. Hal tersebut sesuai dengan pandangan teori konstruktivis yang menyatakan bahwa guru harus dapat membantu siswa untuk menemukan dan membangun pengetahuan dalam diri siswa dengan cara-cara mengajar yang membuat informasi bermmakna dan relevan bagi siswa (Nur; 1998)

3. Kepercayaan (Confidence)

Seorang guru perlu mendasari materi dan situasi, termasuk tingkah laku guru. Untuk menciptakan tingkatan rasa percaya diri sendiri yang cocok dengan harapan siswa agar sukses belajarnya. Misalkan memberitahukan siswa tentang apa yang harus mereka kuasai dan memberikan tugas yang mennatang bagi siswa, tetapi pasti dapat dikerjakan dengan berhasil, serta menerima ujmpan balik yang bersifat kolektif yang membuat siswa mengetahui dimana letak kesalahannya 63 dan bagaimana membetulkannya, merupakan upaya yang baik untuk mengontrol diri sendiri.

Kepercayaan diri juga merupakan aspek penting yang harus juga dicapai dalam pembelajaran. Hal tersebut seperti dijelaskan dalam komptensi yang dikembangkan dalam pendekatan saintifik yaitu Mengembangkan kreativitas, rasa ingin tahu, kemampuan merumuskan pertanyaan untuk membentuk pikiran kritis yang perlu dimulai untuk hidup cerdas dan belajar sepanjang hayat.

4. Kepuasan (Satisfaction)

Agar keinginan belajar dapat berlanjut siswa perlu memiliki rasa puas terhadap proses dan hasil belajarnya. Kepuasan dapat tumbuh dari faktor luar maupun dalam. Faktor luar seperti hadiah, penghargaan, dan nilai ijazah dapat menimbulkan kepuasan. Faktor dalam seperti rasa puas berprestasi, berhasil dengan pekerjaan dan berinteraksi dengan orang lain sangat mempengaruhi kepuasan batiniah (Soeparman, 2000).

Hasil belajar diperoleh pada akhir proses pembelajaran dan berkaitan dengan kemampuan siswa dalam menyerap atau memahami suatu bahan yang telah diajarkan. Seperti yang dikemukakan Dimyati dan Mujiono (2000: 3) bahwa hasil belajar merupakan hasil dari suatu interaksi tindakan belajar dan mengajar. Disisi guru, tindakan mengajar siswa bahkan mampu meningkatkan hasil belajar siswa. Dengan demikian, prestasi atau hasil belajar adalah tingkat keberhasilan yang diperoleh seseorang dari kegiatan belajar yang dinyatakan dalam bentuk nilai

\section{METODE}

Penelitian ini merupakan penelitian tindakan kelas (PTK) dilaksanakan sebanyak 2 siklus dan tiap siklusnya meliputi keigatan perencanaan, pelaksanaan, observasi dan refleksi. Sasaran dalam penelitian ini adalah siswa kelas XI IIS 3 SMAN Jayaloka 
tahun pelajaran 2014/2015 yang berjumlah 26 siswa.

Metode pengumpulan data yang digunakan adalah observasi, angket dan tes. Data yang diperoleh selanjutnya dianalisis secara deskriptif kualitatif.

\section{HASIL DAN PEMBAHASAN}

Hasil pengamatan terhadap proses pemebelajaran menggunakan pendekatan saintifik, pada pertemuan pertama guru belum memancing siswa untuk bertanya apa, mengapa dan bagaimana. Hal ini bisa disebabkan karena subyek yang diamati adalah

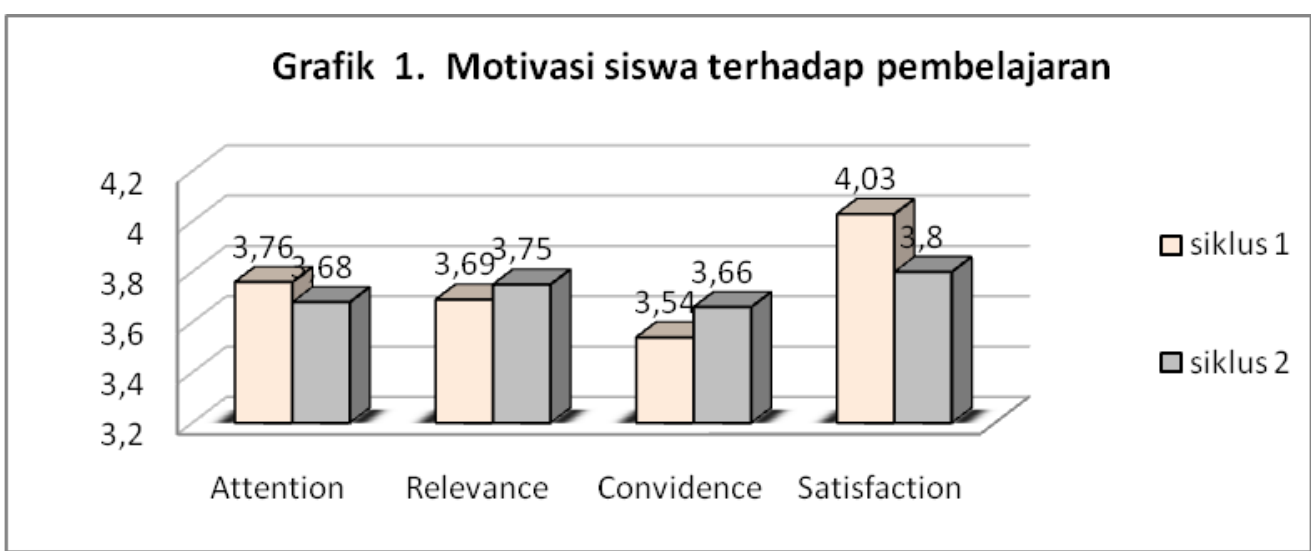

kelas XI IIS 3, yang notabene selama ini belum pernah diajarkan materi Biologi sehingga nampak belum terbiasa untuk membuat pertanyaan. Pada pertemuan kedua juga terjadi hal yang sama. Kemudian pada pertemuan ketiga dan keempat sudah terjadi peningkatan. Aspek keterlaksanaan Bendekatan saintifik sudah dapat berjalan dengan baik. Hal ini dibuktikan dengan isian lembar pengamatan Guru

terhadap proses pemebelajaran sudah diceklis terlaksana.

Dalam penelitian ini data motivasi siswa terhadap pembelajaran dengan menerapkan pendekatan saintifik diperoleh dari angket ARCS (attention, Relevance, Convidence dan Satisfaction) atau dalam bahasa Indonesia sering disebut dengan perhatian, keterkaitan, percaya diri dan kepuasan yang hasilnya dapat diuraikan pada Tabel 1.

Tabel 1. Motivasi siswa terhadap pembelajaran

\begin{tabular}{lcccl}
\hline Aspek & $\begin{array}{c}\text { Siklus } \\
1\end{array}$ & $\begin{array}{c}\text { Siklus } \\
2\end{array}$ & $\begin{array}{c}\text { Rata- } \\
\text { rata }\end{array}$ & Kategori \\
\hline Perhatian & 3.76 & 3.68 & 3.72 & Baik \\
\hline Keterkaitan & 3.69 & 3.75 & 3.72 & Baik \\
\hline Percaya diri & 3.54 & 3.66 & 3.60 & Baik \\
\hline kepuasan & 4.03 & 3.80 & 3.92 & baik \\
\hline
\end{tabular}

Perbandingan motivasi siswa pendekatan saintifik. Pada aspek pada siklus 1 dan 2 terhadap perhatian, keterkaitan, keyakinan dan pembelajaran dengan pendekatan kepuasan dari siklus 1 sampai siklus 2 saintifik hasilnya dapat disajikan pada mengalami peningkatan walaupun tidak Grafik 1

Secara umum motivasi siswa terhadap pemeblajaran dengan melonjak. Rata-rata masing-masing aspek dari siklus pertama sampai siklus kedua berturut-turut yaitu 3,$72 ; 3.72$; 
3.60 dan 3.92 Dengan demikian dapat disimpulkan, bahwa motivasi siswa terhadap pembelajaran dengan pendekatan saintifik adalah baik pada aspek perhatian, keyakinan dan kepuasan. Namun cukup baik pada aspek keterkaitan.

Hasil analisis minat siswa terhadap pembelajaran yang menerapkan pendekatan saintifik disajikan dalam Tabel 2.

Tabel 2. Minat siswa terhadap pembelajaran

\begin{tabular}{lcccl}
\hline \multicolumn{1}{c}{ Aspek } & $\begin{array}{c}\text { Siklus } \\
1\end{array}$ & $\begin{array}{c}\text { Siklus } \\
2\end{array}$ & $\begin{array}{c}\text { Rata- } \\
\text { rata }\end{array}$ & Kategori \\
\hline Perhatian & 3.81 & 3.92 & 3.86 & Baik \\
\hline Keterkaitan & 3.73 & 3.81 & 3.77 & Baik \\
\hline Percaya diri & 3.88 & 3.98 & 3.93 & Baik \\
\hline kepuasan & 3.96 & 4.07 & 4.01 & baik \\
\hline
\end{tabular}

\section{Grafik 2. minat siswa terhadap pembelajaran}

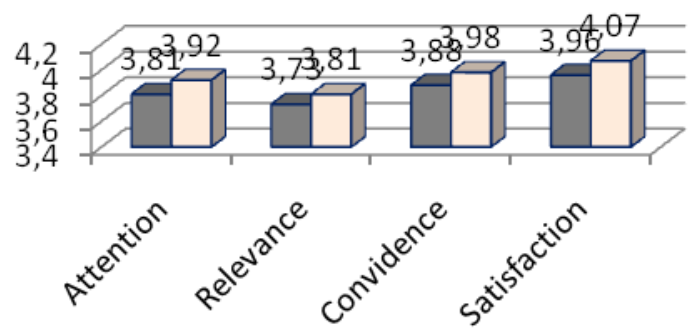

terhadap pembelajaran dengan pendekatan saintifik pada siklus 1 dan 2 dapat disajikan dalam Grafik 2.Secara umum minat siswa terhadap pembelajaran dengan pendekatan saintifik baik. Pada aspek keterkaitan dan keyakinan mengalami peningkatan sedangkan pada aspek kepuasaan tidak mengalami peningkatan. Namun demikian dari semua aspek mengalami peningkatan dari siklus satu dan dua. Rata-rata masing-masing aspek dari siklus pertama sampai siklus kedua berturut-turut, yaitu 3,86; 3,77; 3,93 dan 4,01. Dengan demikian dapat disimpulkan bahwa pembelajaran yang dirancang guru dapat meningkatkan minat siswa untuk belajar.

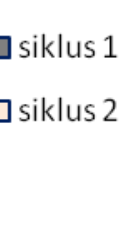

Berdasarkan hasil tes belajar siswa, pada pertemuan pertama terdapat 3 siswa tidak mencapai KKM dan pada siklus kedua terdapat 1 siswa yang tidak mencapai KKM. Dengan demikian jika dipresentase, siswa yang tuntas pada siklus pertama mencapai $88,46 \%$ dan pada siklus kedua mencapai $96,15 \%$.

\section{SIMPULAN}

Berdasarkan hasil penelitian tersebut dapat disimpulkan bahwa pembelajaran biologi yang menerapkan pendekatan saintifik pada kelas XI IIS 3 dapat dilaksanakan dengan baik dan mampu meningkatkan minat, memotivasi dan hasil belajar. 
DAFTAR PUSTAKA

Arikunto S. 2002. Prosedur Penelitian Suatu Pendekatan Praktek. Jakarta: Rineka Cipta

Kardi, Soeparman. 2003. Strategi Motivasi Model ARCS. Surabaya: Program Pendidikan Pasca Sarjana Universitas Negeri Surabaya

Nur Mohamad.2000. Keterampilan Proses. Surabaya: Universitas Negeri Surabaya

Nur M dan Masitoh. 1999. Perkembangan Peserta Didik.
Unipres: Universitas Negeri Surabaya

Nur Mohamad. 1998. Pemotivasian Siswa untuk Belajar. Surabaya: IKIP Surabaya

Sagala Saiful. 2003.Konsep dan Makna Pembelajaran.Bandung: Alfabeta Suradi.2002. Prestasi dan Belajar. Jakarta: Pustaka Widyamara

Tim. 2002. Pedoman Umum Ejaan Yang Disempurnakan. Surabaya: Giri Surya

Tim. Kamus Besar Bahasa Indonesia. 2007. Jakarta: Balai Pustaka www.dadangjsn.blogspot.com [diakses 10 November 2014 